\title{
LONGITUDINAL STUDY OF HEALTH-RELATED QUALITY OF LIFE IN PRIMARY SCHOOL CHILDREN
}

\author{
Zhanna V. Sotnikova-Meleshkina, Nataliia H. Mikhanovska, Hanna E. Ostrovska
}

V. N. Karazin Kharkiv National University

\section{Summary}

Background. The modern medical community considers the quality of life assessment as the main and reliable tool for population-based health surveys, which are extremely relevant in the context of the persistence of the negative trend of its deterioration among school children. Most of the questionnaires are designed for children with pathological conditions, and studies of relatively healthy children are few and relate mainly to aspects of the level of physical activity and sports, and do not take into account the impact of the educational process.

Aim: to determine the dynamics of changes in the quality of life associated with the health of primary school children in the learning process by quantitative and qualitative characteristics

Material and methods. A prospective study was conducted over four school years through a survey using an adapted Ukrainian-language questionnaire for primary school students (624 children aged 7-11) and their parents (616 people). T-test, multiple correlations and one-way analysis of variance in the licensed software package IBM SPSS Statistics v.20.0, graph-models of correlation structures and their system analysis were used for statistical data processing.

Results. The influence of gender, age, and year of study on the scale of relationships with peers, the probable increase in the 4 th grade of school activity according to children, and vice versa, its decrease according to the parental version were revealed. The highest level of quality of life is set on the scale «Emotional activity», and the lowest - on school activities and relationships with adults. During the first two years of study, the main system-forming structures were emotional and physical activities, and in old age, school activity became more important. The largest qualitative differences like the links between the second and third year of the study indicated that this period of study was critical for children, and the reduction in the labilization rate indicated sufficient compensation.

Conclusions. According to the study of the quality of life associated with health in the 4-year dynamics of learning, the most critical period was the transition from the second to the third grade with the preservation of a synchronized system of self-assessment of their condition. The level of physical, emotional and social functioning had certain gender and age characteristics and depended to a greater extent on the period of the educational process. The scales of school activity and socialization in their age group were especially influenced. The study found inconsistency in the perception of school life and satisfaction with communication between children and adults.

Key words: students, quality of life related to health, primary school age; school activities

\section{INTRODUCTION}

The modern medical community considers the quality of life assessment as the main and reliable tool for population research on health status and the impact of social, environmental, psychological, and other factors on it. Such studies are extremely relevant in the context of the persistence of the negative trend of deteriorating health of schoolchildren in recent decades. Thus, according to statistics, only $1 / 10$ of the child population can be considered relatively healthy, about $40 \%$ of children have chronic somatic diseases, $50 \%-$ manifestations of maladaptation [1,2].

The analysis of modern world and domestic publications states that there are numerous studies to determine the quality of life associated with health (BPH) in chil- 
dren with chronic diseases, overweight, sedentary lifestyle [3-5]. Most questionnaires are designed for children with pathological conditions. Both conventional and specific questionnaires are used for their research. Questionnaires PedsQ1 4.0, KIDSCREEN-27,-52, QoL [6-8] are used to assess the performance of children with relatively healthy children, including for the study among schoolchildren (QoLS) [9], but the studies of this category of children are few and relate mainly to aspects of level of physical activity and sports that directly correlate with all scales of quality of life [10-12]. There are only a few works that focus the attention of researchers on the quality of life of children in the educational process [11-13].

Another topical issue is the use of cross-cultural and nationally adapted versions for a certain age of respondents, and for children - the simultaneous use of children's and parents' versions $[14,15]$. As practice shows, to fully assess the quality of life of a child, it is necessary to take into account the results of a survey of all participants in the treatment and education process with psychologists, doctors, teachers, and parents, which helps prevent functional disorders and organic pathology, ability to learn, as well as to detect maladaptive manifestations at the pre-nosological level [16-18].

\section{PURPOSE, MAIN TASKS AND RESEARCH METHODS}

The study was conducted to determine the dynamics of changes in quality of life associated with the health of primary school children in the learning process by quantitative and qualitative characteristics.

For now, an adapted Ukrainian-language methodology has been developed and used, which takes into account both intercultural validation, and the peculiarities of primary school age, and the possibility of parallel research among children and parents [15]. The questionnaire consists of 5 scales. The scale «physical activity» $(\mathrm{PhA})$ involves determining the presence of disease, frequent visits to the doctor, weakness; «School activity» (ScA) problems with concentration and attention, poor school attendance and low academic performance; «Emotional activity» (EmA) - feelings of fear, aggression, tearfulness, sleep disturbances; «Social activity» (SAa) - identifying problems in communicating with peers; «Social activity» (SAc) - the nature of communication with parents, teachers, doctors and other adults.

The prospective study was conducted over four academic years, taking into account the basic principles of the Helsinki Declaration on Biomedical Research and the provisions of the $\mathrm{GCH} \mathrm{ICH}$, in accordance with existing bioethical standards and with the consent of parents. 624 children aged 7-11, studying in grades 1-4 of secondary education and 616 parents took part in the survey. Statistical data processing was performed using t-test, multiple correlation analysis by Pearson's test, systematic analysis of correlation structures by Zosimov A. M. [19], and oneway analysis of variance in the licensed software package SPSS Statistic v. 20. Graph-models of correlation structures were constructed for the systematic analysis of HRQoL indicators, the nodes (vertices) of which were featured, and the edges were reliable connections between them. The average correlation coefficient (ACC), the total labilization/synchronization coefficient (TLC), the indicator of system formation (ISF), and the indicator of correlation difference (ICD) were calculated.

\section{MAIN PART}

According to the results of the analysis of the indicators of HRQoL of primary school students, the highest level was established on the scale «Emotional activity» (EmA; $43.0 \pm 0.6$ points), and the lowest - on school activities (ScA; $36.6 \pm 0.5$ points) and relationships with adults (SAa; $36.8 \pm 0.6$ points). The opposite situation is noteworthy regarding the assessment HRQoL of primary school children by their parents. Thus, in their opinion, children were characterized by a high level of school activity ( $64.2 \pm 0.4$ points) and low socialization in relations with adults ( $28.0 \pm 0.3$ points $)$, which can be regarded on the one hand - as a lack of understanding of the child's problems and inflated demands in communication, and on the other - as a reassessment of academic achievement and motivation for the educational process.

By one-way analysis of variance, the influence of gender on the scale of relationships with peers was revealed $(\mathrm{F}=6.49 ; \mathrm{p}=0.011 ; \%=1.04)$, while in boys this figure was 3.5 points higher. The year of study also affected the indicators of school activity and relationships with peers but had not only a difference in the level of quality of life but also in the period of staying in the educational process (Table 1). Of particular note is the probable increase in the 4th grade of school activity in the opinion of children, and vice versa, its decline in the parental version.

The age peculiarities of HRQoL in children of primary school age were also determined. Thus, the most affected were the indicators of socialization and, if the indicators of school activity according to the results of self-assessment were higher at 11 years $(43.7 \pm 2.6$ points; $\mathrm{p}=0.001)$, and according to parents - at 8 years of age $(66.2 \pm 0.6$ points; $p<0.001)$, the scale of relationships with peers according to both groups of respondents was similar - the highest at 7 years of age (respectively $40.0 \pm$ 1.3 points; $p=0.018$ and $32.1 \pm 0,8$ points; $p=0.004$ ). It should be noted the peculiarities of the questionnaire of parents on the scale «School activity»: regardless of the age of students and year of study, it had the highest indicators (over 60 points) in contrast to the results of self-assessment (not more than 40 points). For children, the emotional coloring of their lives, including the student's, was more important and that was reflected in higher indicators on the scale of emotional activity. 
Health-related quality of life indicators based on the assessment of students and parents

\begin{tabular}{|c|c|c|c|c|c|c|}
\hline Year of study & $\begin{array}{c}\text { Group of } \\
\text { respondents }\end{array}$ & Physical activity & School activity & $\begin{array}{c}\text { Emotional } \\
\text { activity }\end{array}$ & $\begin{array}{c}\text { Social activity } \\
\text { children }\end{array}$ & $\begin{array}{c}\text { Social activity } \\
\text { adults }\end{array}$ \\
\hline \multirow{2}{*}{$1^{\text {st }}$ year of study } & children & $40,73 \pm 1,16$ & $34,62 \pm 1,19^{* 3 \# 4}$ & $44,44 \pm 1,48$ & $40,18 \pm 1,54^{* 2 \# 4}$ & $37,66 \pm 1,26$ \\
\cline { 2 - 7 } & parents & $31,12 \pm 0,83^{* 3}$ & $64,48 \pm 0,64^{\# 4}$ & $35,91 \pm 0,95$ & $31,94 \pm 0,81^{* \# \# 4}$ & $28,25 \pm 0,54$ \\
\hline \multirow{2}{*}{$2^{\text {nd }}$ year of study } & children & $39,94 \pm 0,95$ & $35,42 \pm 0,85^{\# 4}$ & $42,29 \pm 1,14$ & $36,41 \pm 1,02^{* 1}$ & $36,41 \pm 1,04$ \\
\cline { 2 - 7 } & parents & $32,25 \pm 0,74$ & $66,10 \pm 0,55^{\# 4}$ & $37,61 \pm 0,85$ & $32,53 \pm 0,80^{\# 4}$ & $28,46 \pm 0,49$ \\
\hline \multirow{2}{*}{$3^{\text {rd }}$ year of study } & children & $40,07 \pm 0,88$ & $37,84 \pm 1,02^{* 1}$ & $42,52 \pm 1,15$ & $37,59 \pm 1,42^{* 4}$ & $36,44 \pm 1,19$ \\
\cline { 2 - 7 } & parents & $33,59 \pm 0,82^{* 1}$ & $65,29 \pm 0,64^{\# 4}$ & $36,52 \pm 0,88$ & $31,09 \pm 0,97^{* 4}$ & $28,04 \pm 0,70$ \\
\hline \multirow{2}{*}{$4^{\text {th }}$ year of study } & children & $38,76 \pm 0,88$ & $39,38 \pm 0,93^{\# 1 \# 2}$ & $42,74 \pm 1,08$ & $33,58 \pm 1,10^{\# 1^{* *}}$ & $36,72 \pm 1,13$ \\
\cline { 2 - 7 } & parents & $31,67 \pm 0,75$ & $60,16 \pm 0,91^{\# 1 \# 2 \# 3}$ & $36,00 \pm 0,80$ & $27,95 \pm 0,81^{\# 12^{* 3}}$ & $26,96 \pm 0,57$ \\
\hline
\end{tabular}

Note:

$*-\mathrm{p}<0.05$

$\#-\mathrm{p}<0.01$

1 - a significant difference with 1 year of study

2 - a significant difference with 2 years of study

3 - a significant difference with 3 years of study

${ }^{4}$ - a significant difference with 4 years of study

To clarify the nature of the process of age-related changes in the assessment of HRQoL, a correlation analysis was performed with the subsequent construction of graph models of correlation structures (Fig. 1). According to the results of a systematic analysis of the structure of assessment of HRQoL by primary school students of different years of study, it was determined that during the transition from first to second grade and further, until the end of primary school, correlations between all scales were preserved, but their qualitative and quantitative characteristics had certain features.

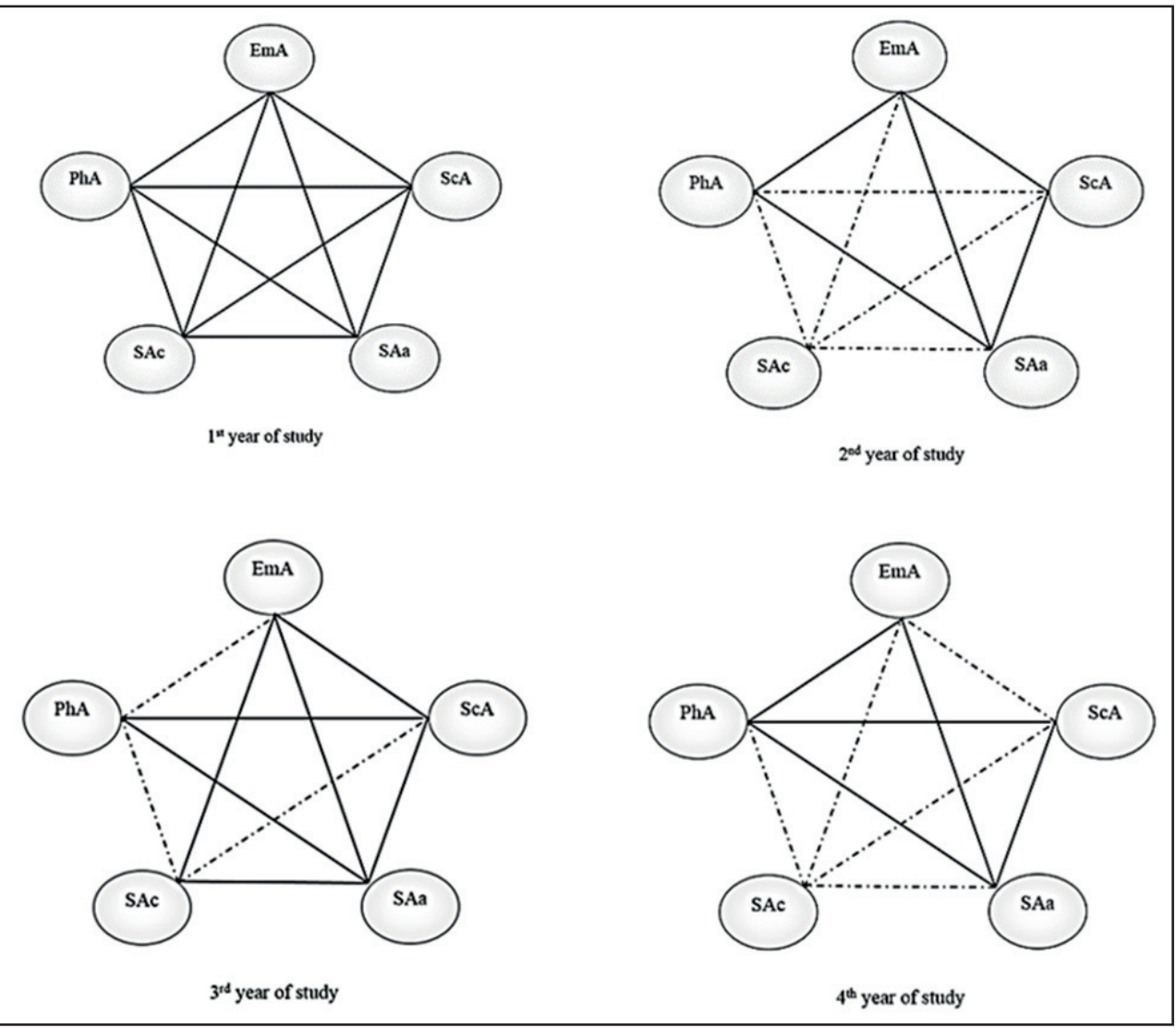

middle correlation $(\mathrm{r}=0.5-0.7 ; \mathrm{p}<0.05)$

- - - - - weak correlation $(r=0.3-0.5 ; \mathrm{p}<0.05)$

Figure 1. Graph-models of correlation structures of quality of life depending on the year of study 
Thus, the indicator of system formation in the 1st and 2 nd grades was an emotional activity that corresponds to the age norms of the child. In the 3rd grade, school activities were the first to contribute to the formation of relationships with other scales, which may indicate that students have reached a certain level of socialization. In the transition to the 4 th class, the system-forming indicator is physical activity. Significant changes were also registered according to the results of ISF ranking with the creation of a hierarchy of system-forming properties of quality of life indicators (Fig. 2). Thus, the first rank on the scale «Emotional Activity» in the 3rd grade changed to the second, and in the 4th grade - to the 3rd position. And, if in 1-2 grades the main system-forming structures were emotional and physical activity, then in old age school activity became more important, which may indicate the formation of a sufficient level of social responsibility and personal self-perception. Under conditions of insufficient adaptive resources, certain somatization is observed, when physical functioning becomes systems

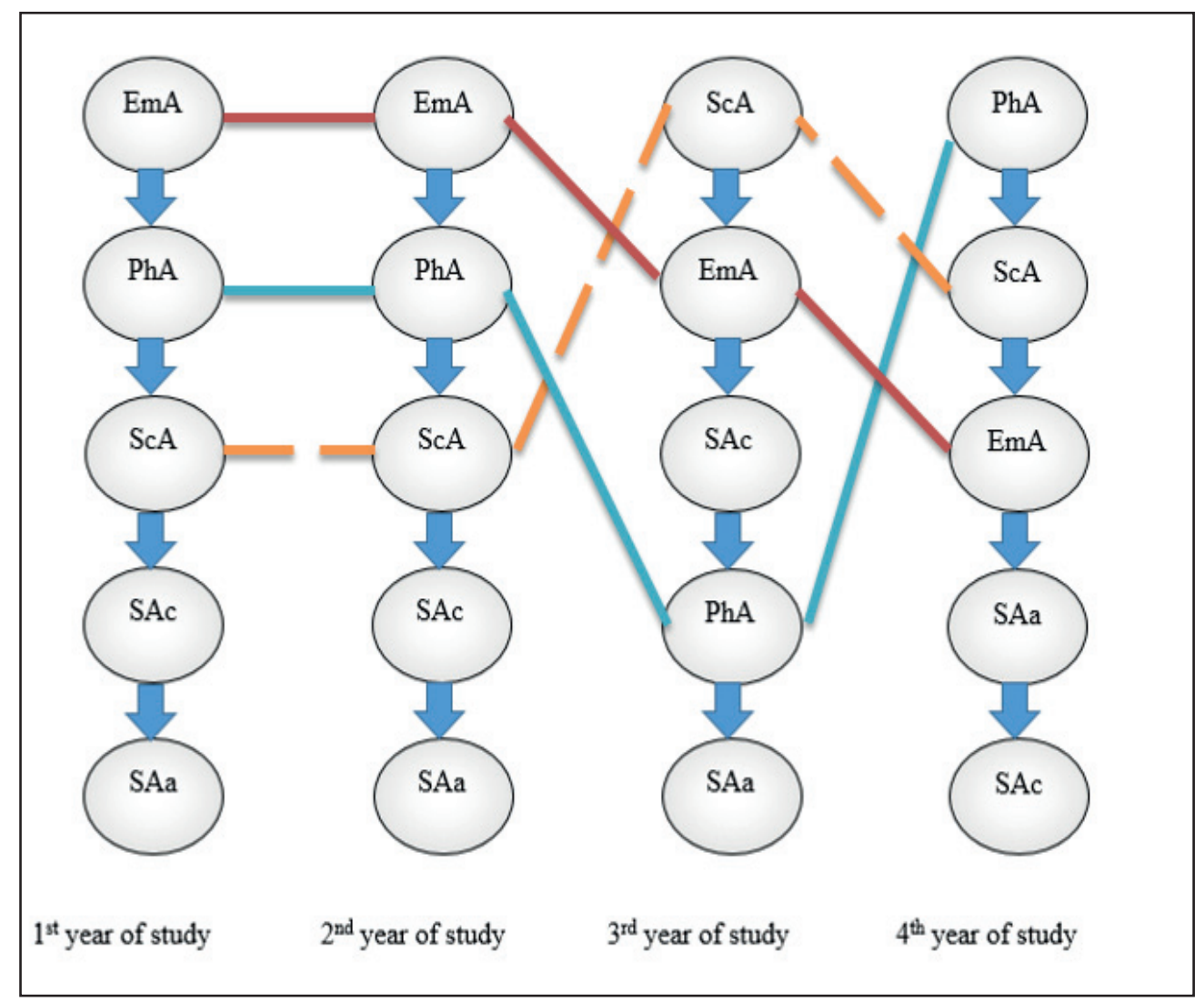

Figure 2. Hierarchy of system-forming properties of HRQoL indicators

If we consider the initial state of students who have just come to school, then the qualitative «portrait» characteristics of the evaluation system of HRQoL has undergone gradual changes from year to year and maximum - in the transition from second to third grade with maintaining the fourth year of stress, which is confirmed by the highest indicator of correlation: $\mathrm{ICD}_{23}-68.4 \%$ (for comparison ICD $12-40.0 \%$, ICD $13^{-47.4 \%}$, ICD

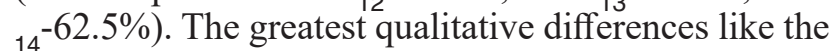
links between the second and third year of the school indicated that this period of study was critical for children.

However, the decrease in the labilization coefficient (TLC) in the 2nd grade from $71.9 \%$ to $59.9 \%$ and some increase in the third grade to $61.2 \%$ from one block confirmed the criticality of this period, and on the other-indicated sufficient compensation and synchronization of the integrated evaluation system of the HRQoL.

\section{CONCLUSIONS}

1. According to the study of the quality of life associated with health in the 4-year dynamics of education in a primary school identified the most critical periods - the transition from the second to the third grade while maintaining a synchronized system of self-assessment of their condition.

2. The level of physical, emotional and social functioning had certain gender and age characteristics and depended to a greater extent on the period of the educational process. The scales of school activity and socialization in their age group were especially influenced. 
3. The study found inconsistency in the perception of school life and satisfaction with communication between children and adults.

Prospects for further development in this direction are to further conduct dynamic observations of the quality of life associated with health in middle school children, identify risk groups for school maladaptation and develop primary preventive measures to prevent it.

The research was performed within the framework of the research topic «Hygienic substantiation of optimal models of strategies for adaptation to the educational activities of left-handed primary school students», № 0119U100678.

\section{ЛІТЕРАТУРА}

1. Нянковський С. Л., Яцула М. С., Нянковська О. С, Титуса А. В. Динаміка стану здоров’я школярів в Україні за даними анкетного опитування. Здоровье ребёнка. 2018. № 13(5). С. 425-431. http:// dx.doi.org/10.22141/2224-0551.13.5.2018.141554

2. Новик А. А., Ионова Т. И. Руководство по исследованию качества жизни в медицине. Практическое пособие. 2007. 320 с.

3. Kesztyüs D., Wirt T., Kobel S., Schreiber A., Kettner S., Dreyhaupt J., Kilian R., Steinacker J. M. Is central obesity associated with poorer health and healthrelated quality of life in primary school children? Cross-sectional results from the Baden-Württemberg Study. BMC Public Health. 2013. Vol.13. Article number 260. https://doi.org/10.1186/1471-2458-13-260

4. Liu W., Lin R., Liu W., Guo Z., Xiong L., Li B., Cheng K. K., Adab P., Pallan M. J., Adab P., Pallan M. Relationship between weight status and healthrelated quality of life in Chinese primary school children in Guangzhou: a cross-sectional study. Health Qual Life Outcomes. 2016. Vol. 14(1). P. 166. https:// doi. org/10.1186/s12955-016-0567-7

5. Wu X. Y., Han L. H., Zhang J. H., Luo S., Hu J. W., Sun K. The influence of physical activity, sedentary behavior on health-related quality of life among the general population of children and adolescents: A systematic review. PLoS One. 2017. Vol. 12(11). Article number: e0187668. https://doi.org/10.1371/journal. pone. 0187668

6. Varni J. W., Katz E. R., Seid M., Knight T. S. The PedsQ1 4.0 generic core Scales: sensitivity, responsiveness, and impact on clinical decision-making. Journal of Behavioral Medicine. 2010. Vol. 25 (2). P. 175-193. https://doi.org/10.1023/a:1014836921812

7. Novik A. A., Ivanova T., Kishtovich A. V. Stratification of patients using Qol parameters by the method of integral profiles. Quality of life research. 2003. Vol. 12(7). P. 770-789. https://www.jstor.org/stable/4038411

8. Гатиятуллина Л. Р., Малиевский В. А., Винярская И. В., Коновалова Г. М. Показатели качества жизни детей младшего школьного возраста в республике Башкортостан. Российский педиатрический журнал. 2014. № 5 (17). С. 34-38. https:// www.elibrary.ru/item.asp?id=22598430
9. Weintraub N., Bar-Haim Erez A. Quality of Life in School (QoLS) Questionnaire: Development and Validity. The American Journal of Occupational Therapy. 2009. Vol. 63(6). P. 724-31. https://doi.org/10.5014/ajot.63.6.724

10. Moeijes J., van Busschbach J. T., Bosscher R. J., Twisk J. W. R. Sports participation and health-related quality of life: a longitudinal observational study in children. Quality of Life Research. 2019. Vol. 28(9). P. 2453-2469. https://doi.org/10.1007/s11136-019-02219-4

11. Hyndman B., Benson A. C., Lester L., Telford A. Is there a relationship between primary school children's enjoyment of recess physical activities and healthrelated quality of life? A cross-sectional exploratory study. Health Promotion Journal of Australia. 2017. Vol. 28(1). P. 37-43. https://doi.org/10.1071/he15128

12. Shoesmith A., Hall A., Hope K., Sutherland R., Hodder R. K., Trost S. G., Lecathelinais C., Lane C., McCarthy N., Nathan N. Associations between inschool-hours physical activity and child health-related quality of life: A cross-sectional study in a sample of Australian primary school children. Preventive Medicine Reports. 2020. Vol. 20. Article number: 101179. https://doi.org/10.1016/j.pmedr.2020.101179

13. Даниленко Г. М., Міхановська Н. Г., СотніковаМелешкіна Ж.В., Голубнича Г. І. Комплексний підхід щодо визначення психофізіологічної складової шкільної дезадаптації у молодших школярів за різних систем освіти. East European Scientific Journal. 2019. № 6(46). Ч. 2. C. 16-23. https://eesajournal.com/wp-content/uploads/EESA_June2.pdf

14. Laaksonen C., Aromaa M., Heinonen O. J., Suominen S., Salanterä S. Paediatric health-related quality of life instrument for primary school children: cross-cultural validation. Journal of Advanced Nursing. 2007. Vol. 59(5). P. 542-550. https://doi. org/10.1111/j.1365-2648.2007.04347.x

15. Спосіб оцінки якості життя, зв'язаної зі здоров'ям молодших школярів. пат. 28576 Україна: МПК (2006) A61B 1/00 A61B 5/00. № u200709955; опубл. 10.12.2007, Бюл. № 20. 4 c.

16. Catchpool M., Gold L., Grobler A. C., Clifford S. A., Wake M. Health-related quality of life: population epidemiology and concordance in Australian children aged 11-12 years and their parents. BMJ Open. 
2019. Vol. 3. P. 157-164. https://doi.org/10.1136/ bmjopen-2018-022398

17. Ólafsdóttir L. B., Egilson S. T., Árnadóttir U., Hardonk S. C. Child and parent perspectives of life quality of children with physical impairments compared with non-disabled peers. Scandinavian Journal of Occupational Therapy. 2019. Vol. 26. No. 7. P. 496-504. https://doi.org/10.1080/11038128.2018.1509371
18. Hemmingsson H., Ólafsdóttir L. B., Egilson S. T. Agreements and disagreements between children and their parents in health-related assessments. Disability and Rehabilitation. 2017. Vol. 39(11). P. 1059-1072. https://doi.org/10.1080/09638288.2016 .1189603

19. Зосимов А. Н. Системный анализ в медицине / А. Н. Зосимов, В. П. Голик. Х.: Торнадо, 2000. 78 с.

\section{REFERENCES}

1. Nyankovs'kyy, S.L., Yatsula, M.S., Nyankovs'ka, O.S, Tytusa, A.V. (2018). Dynamika stanu zdorov"ya shkolyariv v Ukrayini za danymy anketnoho opytuvannya [Dynamics of the state of health of schoolchildren in Ukraine according to the questionnaire]. Zdorov'e rebenka, 13(5), 425-431. http://dx.doi.org/10.2214 $1 / 2224-0551.13 .5 .2018 .141554$

2. Novik, A.A., Ionova, T.I. (2007). Rukovodstvo po issledovaniyu kachestva zhizni v meditsine. Prakticheskoye posobiye [Guidelines for the study of quality of life in medicine. Practical guide]. Moscow, 320.

3. Kesztyüs, D., Wirt, T., Kobel, S., Schreiber, A., Kettner, S., Dreyhaupt, J., Kilian, R., Steinacker, J. M. (2013). Is central obesity associated with poorer health and health-related quality of life in primary school children? Cross-sectional results from the Baden-Württemberg Study. BMC Public Health, (13) Article number 260. https://doi. org/10.1186/1471-2458-13-260

4. Liu, W., Lin, R., Liu, W., Guo, Z., Xiong, L., Li, B. ... Pallan, M. (2016). Relationship between weight status and health-related quality of life in Chinese primary school children in Guangzhou: a cross-sectional study. Health Qual Life Outcomes, 14(1), 166. https://doi. org/10.1186/s12955-016-0567-7

5. Wu, X. Y., Han, L. H., Zhang, J. H., Luo, S., Hu, J. W., Sun, K. (2017).The influence of physical activity, sedentary behavior on health-related quality of life among the general population of children and adolescents: A systematic review. PLoS One, 2017. 12(11). Article number: e0187668. https://doi.org/10.1371/ journal.pone. 0187668

6. Varni, J. W., Katz, E. R., Seid, M., Knight, T. S. (2010). The PedsQ1 4.0 generic core Scales: sensitivity, responsiveness, and impact on clinical decision-making. Journal of Behavioral Medicine, 25(2), 175-193. https://doi.org/10.1023/a:1014836921812

7. Novik, A. A., Ivanova, T., Kishtovich, A. V. (2003). Stratification of patients using Qol parameters by the method of integral profiles. Quality of life research, 12(7), 770-789. Retrieved from https://www.jstor.org/ stable/4038411

8. Gatiyatullina, L. R., Maliyevskiy, V. A., Vinyarskaya, I. V., Konovalova, G. M. (2014). Pokazateli kachest- va zhizni detey mladshego shkol'nogo vozrasta v respublike Bashkortostan. [Indicators of the quality of life of children of primary school age in the Republic of Bashkortostan]. Russian Pediatric Journal, 5(17), 34-38. Retrieved from https://www.elibrary.ru/item. asp?id=22598430

9. Weintraub, N., Bar-Haim Erez, A. (2009). Quality of Life in School (QoLS) Questionnaire: Development and Validity. The American Journal of Occupational Therapy, 63(6), 724-31. https://doi.org/10.5014/ajot.63.6.724

10. Moeijes, J., van Busschbach, J. T., Bosscher, R. J., Twisk, J. W. R. (2019). Sports participation and health-related quality of life: a longitudinal observational study in children. Quality of Life Research, 28(9), 2453-2469. https://doi.org/10.1007/ s11136-019-02219-4

11. Hyndman, B., Benson, A. C., Lester, L., Telford, A. (2017). Is there a relationship between primary school children's enjoyment of recess physical activities and health-related quality of life? A cross-sectional exploratory study. Health Promotion Journal of Australia, 28(1), 37-43. https://doi.org/10.1071/he15128

12. Shoesmith, A., Hall, A., Hope, K., Sutherland, R., Hodder, R. K., Trost, S. G. ... Nathan, N. (2020). Associations between in-school-hours physical activity and child health-related quality of life: A crosssectional study in a sample of Australian primary school children. Preventive Medicine Report, 20. Article number: 101179. https://doi.org/10.1016/j. pmedr.2020.101179

13. Danylenko, H.M., Mikhanovska, N.H., SotnikovaMeleshkina, ZH.V., Holubnycha, H. I. (2019). Kompleksnyy pidkhid shchodo vyznachennya psykhofiziolohichnoyi skladovoyi shkil'noyi dezadaptatsiyi u molodshykh shkolyariv za riznykh system osvity.[A comprehensive approach to determining the psychophysiological component of school maladaptation in primary school children in different education systems]. East European Scientific Journal, 6(46) p.2., 16-23. Retrieved from https://eesa-journal.com/ wp-content/uploads/EESA_June2.pdf

14. Laaksonen, C., Aromaa, M., Heinonen, O. J., Suominen, S., Salanterä, S. (2007). Paediatric health-related quality of life instrument for prima- 
ry school children: cross-cultural validation. Journal of Advanced Nursing, 59(5), 542-550. https://doi. org/10.1111/j.1365-2648.2007.04347.x

15. Sposib otsinky yakosti zhyttya, zv'yazanoyi zi zdorov'yam molodshykh shkolyariv. [A method of assessing of health-related quality of life of primary school children]. pat. UA 28576: MPK (2006) A61B 1/00 A61B 5/00. № u200709955; publ. 10.12.2007, Bull. № 20. 4 c.

16. Catchpool, M., Gold, L., Grobler, A. C., Clifford, S. A., Wake, M. (2019). Health-related quality of life: population epidemiology and concordance in Australian children aged 11-12 years and their parents. BMJ Open, 3, 157-164. https://doi.org/10.1136/bmjopen-2018-022398
17. Ólafsdóttir, L. B., Egilson, S. T., Árnadóttir, U., Hardonk, S. C. (2019). Child and parent perspectives of life quality of children with physical impairments compared with non-disabled peers. Scandinavian Journal of Occupational Therapy, 26(7), 496-504. https://doi. org/10.1080/11038128.2018.1509371

18. Hemmingsson, H., Ólafsdóttir, L. B., Egilson, S. T. (2017). Agreements and disagreements between children and their parents in health-related assessments. Disability and Rehabilitation, 39(11), 1059-1072. https://doi.org/10.1080/09638288.2016.1189603

19. Zosimov, A.N., Golik, V.P. (2000). Sistemnyy analiz v meditsine. [System analysis in medicine]. Kharkiv: Tornado.

\section{Резюме}

\section{ЛОНГІТЮДНЕ ДОСЛІДЖЕННЯ ЯКОСТІ ЖИТТЯ, ЩО ПОВ'ЯЗАНА ЗІ ЗДОРОВ'ЯМ ДІТЕЙ МОЛОДШОГО ШКІЛЬНОГО ВІКУ \\ Сотнікова-Мелешкіна Ж.В., Міхановська Н. Г., Островська Г. Є.}

Харківський національний університет імені В. Н. Каразіна, Харків, Україна

Сучасна медична спільнота розглядає оцінку якості життя як основний та надійний інструмент популяційних досліджень стану здоров'я, вкрай актуальних в умовах зберігання негативної тенденції щодо погіршення його серед школярів. Білышість з опитувальників розрахована на дітей з патологічними станами, а дослідження умовно здорових дітей малочисельні і стосуються переважно аспектів рівня фізичної активності та занять спортом, і не враховують впливу навчального процесу.

Мета дослідження. визначення динаміки змін якості життя, що пов'язана зі здоров'ям дітей молодшого шкільного віку у процесі навчання за кількісними та якісними характеристиками

Матеріал і методи. Проведено проспективне дослідження упродовж чотирьох навчальних років шляхом опитування за допомогою адаптованої україномовної анкети для учнів молодшого шкільного віку (624 дитини віком 7-11 років) та їх батьків (616 осіб). Аля статистичної обробки даних використано t-тест, множинний кореляційний та однофакторний дисперсійний аналіз у ліцензованому програмному пакеті SPSS Statistic v. 20, граф-моделі кореляційних структур та їх системний аналіз.

Результати. Встановлено вплив статі, віку та року навчання на шкалу взаємовідносин з однолітками, вірогідне зростання к 4-му класу шкільної активності за думкою дітей, та навпаки, її зниження за батьківською версією. Найвищий рівень якості життя встановлений за шкалою «Емоційна діяльність», а найнижчий - за шкільною діяльністю та відношеннями з дорослими. Протягом перших двох років навчання головними системоутворюючими структурами виступали емоційна та фізична діяльність, а у старшому віці білыш важливою становилась шкільна активність. Найбільші якісні розходження у характері зв'язків між другим та третім роком навчання свідчили про критичність саме цього періоду навчання для дітей, а зниження коефіцієнту лабілізаціі про достатню компенсацію.

Висновки. За даними вивчення якості життя, що пов'язана зі здоров'ям у 4-річній динаміці навчання найбільш критичним визначався період переходу з другого до третього класу із збереженням синхронізованої системи самооцінювання свого стану. Рівень фізичного, емоційного та соціального функціонування мав певні статеві та вікові особливості і у більшій мірі залежав від періоду навчального процесу. Особливого впливу зазнавали шкали шкільної діяльності та соціалізації у своїй віковій групі. Аослідженням встановлено неконгруентність сприйняття шкільного життя та задоволеності від спілкування між дітьми та дорослими.

Ключові слова: учні; якість життя, що пов'язана зі здоров'ям; молодший шкільний вік; шкільна діяльність 


\title{
Резюме
}

\section{ЛОНГИТЮДНОЕ ИССЛЕДОВАНИЕ КАЧЕСТВА ЖИЗНИ, СВЯЗАННОГО СО ЗДОРОВЬЕМ ДЕТЕЙ МЛАДШЕГО ШКОЛЬНОГО ВОЗРАСТА}

Сотникова-Мелешкина Ж.В., Михановская Н. Г., Островская А. Е.

\author{
Харьковский национальный университет имени В. Н. Каразина, Харьков, Украина
}

Современное медицинское сообщество рассматривает оценку качества жизни как основной и надежный инструмент популяционных исследований состояния здоровья, крайне актуальных в условиях сохранения негативной тенденции ухудшения его среди школьников. Болышинство из опросников рассчитана на детей с патологическими состояниями, а исследования условно здоровых детей малочисленные и касаются в основном аспектов уровня физической активности и занятий спортом, и не учитывают влияния учебного процесса.

Цель исследования. Определения динамики изменений качества жизни, связанного со здоровьем детей младшего школьного возраста в процессе обучения по количественным и качественным характеристикам Материал и методы. Проведено проспективное исследование в течение четырех учебных лет путем опроса с помощью адаптированной украиноязычной анкеты для учащихся младшего школьного возраста (624 ребенка в возрасте 7-11 лет) и их родителей (616 человек). Аля статистической обработки данных использованы t-тест, множественный корреляционный и однофакторный дисперсионный анализ в лицензированном программном пакете SPSS Statistic v. 20, граф-модели корреляционных структур и их системный анализ.

Результаты. Установлено влияние пола, возраста и года обучения на шкалу взаимоотношений со сверстниками, достоверный рост к 4-му классу школьной активности по мнению детей, и наоборот, ее снижение по родительской версии. Самый высокий уровень качества жизни установлен по шкале «Эмоциональная деятельность», а самый низкий - по школьной деятельностью и отношениями со взрослыми. В течение первых двух лет обучения главными системообразующими структурами выступали эмоциональная и физическая деятельность, а в старшем возрасте более важной становилась школьная активность. Наибольшие качественные различия в характере связей между вторым и третьим годом обучения свидетельствовали о критичности именно этого периода обучения дхя детей, а снижение коэффициента лабилизации о достаточной компенсации.

Выводы. По данным изучения качества жизни, связанного со здоровьем в 4-летней динамике обучения наиболее критическим определялся период перехода со второго в третий класс с сохранением синхронизированной системы самооценки своего состояния. Уровень физического, эмоционального и социального функционирования имел определенные половые и возрастные особенности и в болышей степени зависел от периода учебного процесса. Особому влиянию подвергались шкалы школьной деятельности и социализации в своей возрастной группе. Исследованием установлена неконгруэнтность восприятия школьной жизни и удовлетворенности от общения между детьми и взрослыми.

Ключевъе слова: учащиеся; качество жизни, связанное со здоровьем; младший школьный возраст; школьная деятельность

Інформація про авторів знаходиться на сайті http://www.cp-medical.com.

Дата надходження до редакції-29.10.2020 